This is an open-access article distributed under the terms of the Creative Commons Attribution License, which permits unrestricted use, distribution, and reproduction in any medium, provided the original author(s) and source are credited.

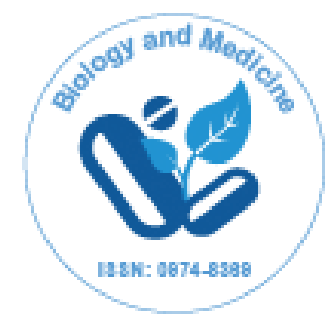

ISSN: 0974-8369

\title{
Biology and Medicine
}

\author{
International, Open Access
}

\section{Available online at: www.biolmedonline.com}

7 his article was originally published in this journal and the attached copy is provided for the author's benefit and for the benefit of the author's institution, for commercial/research/educational use including without limitation use in instruction at your institution, sending it to specific colleagues that you know, and providing a copy to your institution's administrator.

All other uses, reproduction and distribution, including without limitation commercial reprints, selling or licensing copies or access, or posting on open internet sites, your personal or institution's website or repository, are requested to cite properly. 


\title{
Extraction and Purification of Pectolytic Enzyme Using Combined Method
}

\author{
Madina Adilbiyevna Dzhakasheva ${ }^{1, *}$, Bahytzhan Shilmirzayevich Kedelbayev ${ }^{1}$, Zhanar Rahmanberdiyevna Elemanova ${ }^{1}$, \\ Assiya Yrsymbekovna Mamytova ${ }^{2}$, Utepbergen Kosherbayevich Bissenov ${ }^{3}$
}

${ }^{1}$ Auezov South-Kazakhstan State University, 5, Taukekhan Avenue, Shymkent 160000, Republic of Kazakhstan

${ }^{2}$ South Kazakhstan State Pedagogical Institute, 13, Baitursynov Street, Shymkent 160000, Republic of Kazakhstan

${ }^{3}$ Dosmukhamedov Atyrau State University, 212, Students Avenue, Atyrau 060011, Republic of Kazakhstan

\begin{abstract}
As a consequence of development of combined method of purification and extraction of pectolytic enzyme, we have produced the enzyme with higher polygalacturonase (PGA) activity with a sufficiently high yield of the final product. The method is based on consecutive removal of individual groups of inactive impurities from enzyme solutions by means of activated charcoal and anion-exchange resin. Application of hydroxyapatite makes it possible to achieve activation of pectinases by removal of low molecular proteins. The absence of pectins and carbohydrates facilitates its usage in winemaking for clarification of superior wine grads and removal of wine stone composed of pectin substances of grape juice.
\end{abstract}

\section{Keywords}

Pectolytic enzyme; Polygalacturonase; Activated charcoal; Anionexchange resin; Hydroxyapatite

\section{Introduction}

Pectolytic enzymes (pectinases) are the ones which catalyze decomposition of pectic substances [1]. Increased interest in pectolytic enzymes is stipulated by their application in complicated bioengineering processes, such as obtaining physiologically active products of oriented enzymatic hydrolysis of pectic polysaccharides [2]. Pectinases were the first enzymes which were used in the fruit-processing industry; their initial application had been reported already in the 1930s [3,4]. For most fruits the use of pectinase is an obligatory condition of processing [5]; upon processing of grapes for wine production [6], the use of pectinase is not an obligatory engineering condition, but it improves the final quality. This is why winemaking involves various substances with pectinase. This is stipulated by two peculiar features of commercial pectinases. Firstly, pectinase is not a single enzyme, but, rather, a set of several pectin-splitting substances: pectinesterases, polygalacturonases, pectin lyases, and pectate lyases. Secondly, commercial pectinases are not pure enzymes and are usually characterized with secondary activity (which depends on the applied enzyme), which provides advantages (or stipulates disadvantages) in grape processing. The secondary activity is evident in the fact that pectinases act as cellulase, hemicellulase, $\beta$-glucanase, $\beta$-glycosidase, and protease $[7,8]$.

Enzyme purification and extraction methods depend on applied use of the obtained pectolytic substance. Engineering purposes can be performed using raw enzyme, whereas enzyme application in food industry requires for obligatory purification [9]. It is known that the difficulties occurring upon production of highly purified pectolytic enzymes are defined by the fact that pectinases are mostly glycoproteins, where oligosaccharide remainders are coupled with protein molecules by covalent bonds. As a consequence of ionic and hydrophobic interactions between the enzyme and substrate enzyme, substrate complexes can be generated in culture liquids, which have the properties of individual compounds. The enzymesubstrate complexes can be destroyed upon variation of the medium's acidity and ionic strength of solution as a consequence of thermal dissociation or due to displacement of substrate remainders upon generation of stronger ionic pairs of enzyme molecules with other compounds [10].
Existence of carbohydrates and pectic substances in the enzyme can falsify significantly the results of analysis of fermentolysis products of pectic polysaccharides and hinder extraction of physiologically active fragments [11]. Therefore, development of production of highly purified and highly active pectolytic enzymes is very urgent.

\section{Materials and Methods}

Filamentous fungus Aspergillus awamori 56-2-53-85-375 was obtained as a consequence of multistage selection and mutagenesis by experts of the Chair of Biotechnology, Auezov South-Kazakhstan State University; it exists on slanting wort agar at $4^{\circ} \mathrm{C}$.

Activity of the pectolytic complex of enzymes was determined according to the procedure described in valid Standard GOST 20264.3-81. Specific activity of the enzymes was calculated as the ratio of solution activity (units $/ \mathrm{ml}$ ) to total content of protein $(\mathrm{mg} / \mathrm{ml})$. Unit pectolytic activity was defined as the amount of enzyme which catalyzes hydrolysis of $1 \mathrm{~g}$ of pectin to products not deposited by zinc sulfate upon hydrolysis under strictly defined conditions: $\mathrm{t} 30^{\circ} \mathrm{C}, \tau 1 \mathrm{~h}, \mathrm{pH} 4$; enzyme to substrate ratio in reactive medium providing hydrolysis of $30 \%$ pectin taken for reaction. Activity loss of enzyme solutions was calculated by the ratio of difference between initial and final activity values of pectinase to its initial value expressed in percentages. Protein content was determined by the Lowry method [12].

Activated coals for purification of culture liquid was preliminarily milled and subdivided into fractions by sieving for obtaining of granules with the particle sizes from 100 to $280 \mu \mathrm{m}$. A $1,000 \mathrm{ml}$ of culture liquid at $4^{\circ} \mathrm{C}$ was mixed with microporous coals, the mixture was agitated in a magnetic stirrer for $30 \mathrm{~min}$, and then the sorbent was separated by filtration under vacuum in a Dolphin LC 0030 A water

\footnotetext{
*Corresponding author: Dzhakasheva MA, Auezov South-Kazakhstan State University, 5, Taukekhan Avenue, Shymkent 160000, Republic of Kazakhstan.

Received: Mar 9, 2016; Accepted: Mar 17, 2016; Published: Apr 13, 2016

Citation: Dzhakasheva MA, Kedelbayev BSh, Elemanova ZhR, Mamytova AY, Bissenov UK (2016) Extraction and Purification of Pectolytic Enzyme Using Combined Method. Biol Med (Aligarh) 8(2): BM-174-16, 4 pages.

Copyright: (c) 2016 Dzhakasheva et al. This is an open-access article distributed under the terms of the Creative Commons Attribution License, which permits unrestricted use, distribution, and reproduction in any medium, provided the original author and source are credited.
} 
ring pump (Busch, Germany). Protein content and pectinase activity were determined in the filtrate. The content of pectic substances in culture liquids was determined by color index by measurement of optical density using a KFK-2 photocolorimeter at a wave length of $315 \mathrm{~nm}$. The purification degree in terms of color index was estimated as the ratio of difference between initial and final activity values of pectinase to its initial value expressed in percentages.

The filtrate of culture liquid was processed by a A500P strong-base ion-exchange resin in the amount of $80 \mathrm{~g} / \mathrm{l}$ with subsequent agitation of the slurry for $30 \mathrm{~min}$ at $\mathrm{pH} 4$ and $4^{\circ} \mathrm{C}$, and then the adsorbent was separated by filtration under vacuum in a Dolphin LC $0030 \mathrm{~A}$ water ring pump (Busch, Germany). Acidity of the solution was adjusted by an addition of $0.1 \mathrm{M}$ sodium hydroxide into the medium.

Pectolytic enzyme was activated by nanosized Si-hydroxyapatite, which was synthesized by the procedure of deposition from solutions described elsewhere [13]. Saturated solution of calcium hydroxide and solution of orthophosphoricacid were used as reagents. Tetraethoxysilane was used as the "supplier" of $\mathrm{SiO}_{4}^{4-}$ anion. Average crystalline size of the obtained powders was determined by the Williamson-Hall method using a Rigaku Ultima IV diffractometer, and specific surface area was determined low temperature adsorption and thermal sorption of nitrogen (Brunauer-Emmett-Teller (BET) theory) using a TriStar II 3020 gas-adsorption analyzer. Nanosized Si-hydroxyapatite was added to a partially purified enzyme solution in the concentration of $30 \mathrm{~g} / \mathrm{l}$ for $30 \mathrm{~min}$ at $4^{\circ} \mathrm{C}$ and $\mathrm{pH}$ 6. After separation of gel from the enzyme solution by filtration under vacuum in a Dolphin LC 0030 A water ring pump (Busch, Germany), the gel was rinsed in distilled water. Desorption of enzymes was carried out by processing of gel in $0.3 \mathrm{M}$ phosphate buffer at $\mathrm{pH}$ 7.0. Then the enzyme solution was stabilized by acidification with $0.1 \mathrm{M}$ acetic acid up to $\mathrm{pH} 4.0$.

The stabilized enzyme solution was desalinized by diafiltration on a UF-8-50-PS hollow fiber membrane unit (Fazerkraft, Russia) with a transport limit of $30 \mathrm{kDa}$ at continuous addition of acetate buffer with $\mathrm{pH} 4.0$ in order to maintain a constant volume of the enzyme solution. Then the solution was concentrated using ultrafiltration up to $100 \mathrm{ml}$ using the same membrane unit with the transport limit of $30 \mathrm{kDa}$ at a stabilized pressure of $0.1 \mathrm{MPa}$. Dry pectolytic enzyme was obtained by lyophilization of purified solution using an LGJ-1A-80 freeze drier in three stages: freezing of solution up to $-40^{\circ} \mathrm{C}$, sublimation of water and drying of sample.

Estimation of the results and their statistic confidence was performed using MathCAD and Statistica software packages.

\section{Results and Discussion}

Previously experts of the Chair of Biotechnology, Auezov SouthKazakhstan State University, using multistage selection obtained producer strain A. awamori 56-2-53-85-375, which synthesized pectinase with the activity of 2.1 units/ml [14].

The method of extraction and purification of pectolytic enzyme was developed with consideration not only for efficiency of individual physicochemical methods upon elimination of various groups of inactive impurities but also for selectivity and activating impact on enzymes.

In order to remove low molecular impurities from culture liquid, such as pectic substances, activated microporous coals, grades SKT, BAU-B, and KAD-G, were applied. Activated coals are porous carbon adsorbent with developed internal surface, consisting of open pores

\begin{tabular}{|c|c|c|c|c|c|}
\hline $\begin{array}{l}\text { Type of } \\
\text { charcoal }\end{array}$ & $\begin{array}{l}\text { Treatment } \\
\text { conditions }\end{array}$ & Value & $\begin{array}{c}\text { Specific } \\
\text { activity, } \\
\text { units } / \mathrm{mg} \\
\text { protein }\end{array}$ & $\begin{array}{l}\text { Purification } \\
\text { degree in } \\
\text { terms of color } \\
\text { index, } \%\end{array}$ & $\begin{array}{c}\text { PTA } \\
\text { activity } \\
\text { loss, \% }\end{array}$ \\
\hline \multirow{10}{*}{ SKT } & \multirow{6}{*}{$\begin{array}{l}\mathrm{pH} \text { of culture } \\
\text { liquid }\end{array}$} & 3.0 & 77.0 & 63 & 0.5 \\
\hline & & 3.5 & 81.0 & 65 & 1.5 \\
\hline & & 4.0 & 80.8 & 64 & 2.8 \\
\hline & & 4.5 & 76.0 & 57 & 3.0 \\
\hline & & 5.0 & 71.3 & 50 & 4.5 \\
\hline & & 5.5 & 63.4 & 44 & 6.3 \\
\hline & \multirow{4}{*}{$\begin{array}{c}\text { Sorbent } \\
\text { dosage, g/l }\end{array}$} & 5 & 65.0 & 48 & 4.0 \\
\hline & & 10 & 82.0 & 54 & 6.5 \\
\hline & & 15 & 81.4 & 61 & 22.0 \\
\hline & & 20 & 78.0 & 66 & 28.0 \\
\hline \multirow{10}{*}{ BAU-B } & \multirow{6}{*}{$\begin{array}{l}\mathrm{pH} \text { of culture } \\
\text { liquid }\end{array}$} & 3.0 & 91.2 & 70 & 1.0 \\
\hline & & 3.5 & 95.0 & 71 & 2.5 \\
\hline & & 4.0 & 91.8 & 68 & 4.4 \\
\hline & & 4.5 & 85.0 & 64 & 6.8 \\
\hline & & 5.0 & 77.0 & 52 & 9.0 \\
\hline & & 5.5 & 63.0 & 44 & 14.3 \\
\hline & \multirow{4}{*}{$\begin{array}{c}\text { Sorbent } \\
\text { dosage, g/l }\end{array}$} & 5 & 73.0 & 50 & 20.0 \\
\hline & & 10 & 89.4 & 54 & 25.0 \\
\hline & & 15 & 85.5 & 59 & 37.0 \\
\hline & & 20 & 79.0 & 67 & 42.0 \\
\hline \multirow{10}{*}{ KAD-G } & \multirow{6}{*}{$\begin{array}{l}\mathrm{pH} \text { of culture } \\
\text { liquid }\end{array}$} & 3.0 & 90.1 & 75 & 0.3 \\
\hline & & 3.5 & 94.0 & 75 & 0.8 \\
\hline & & 4.0 & 90.8 & 73 & 1.5 \\
\hline & & 4.5 & 88.0 & 70 & 1.8 \\
\hline & & 5.0 & 85.3 & 60 & 3.0 \\
\hline & & 5.5 & 81.0 & 50 & 5.6 \\
\hline & \multirow{4}{*}{$\begin{array}{c}\text { Sorbent } \\
\text { dosage, g/l }\end{array}$} & 5 & 83.0 & 54 & 2 \\
\hline & & 10 & 97.5 & 63 & 4.8 \\
\hline & & 15 & 91.4 & 70 & 18 \\
\hline & & 20 & 95.0 & 77 & 25 \\
\hline
\end{tabular}

Table 1: Influence of treatment of culture liquid by activated charcoals

and capillary channels with the volume of $0.23-0.26 \mathrm{ml} / \mathrm{g}$ [15]. Table 1 summarizes the values of purification degree in terms of color index as a function of $\mathrm{pH}$ upon processing of the culture liquid obtained after cultivation of filamentous fungus A. awamori 56-2-53-85-375 activated by coals, grades SKT, BAU-B, and KAD-G and their dosage.

The obtained data demonstrate that in the $\mathrm{pH}$ range of 3.0-3.5 for all considered grades of activated microporous coals, the highest efficiency of purification of enzyme solutions is obtained. It can be seen in Table 1 that at optimum $\mathrm{pH}$ the influence of sorbent dosage in the culture liquid on purification efficiency is directly proportional. High efficiency upon discoloration and purification of the solution is observed with the use of coal, grade KAD-G, with the concentration of $10 \mathrm{~g} / \mathrm{l}$.

Activated coal KAD-G is usually applied for removal of organic impurities from waste waters upon production of galvanic coatings as well as for purification of recycled and processed waters. Its major properties are as follows: grain sizes, $\mathrm{mm}$ : 1.0-2.8; bulk density, $\mathrm{g} / \mathrm{dm}^{3}$ : $<460$; strength, \%: $>70$; total pore volume, $\mathrm{cm}^{3} / \mathrm{g}:>0.7$; volume of micropores, $\mathrm{cm}^{3} / \mathrm{g}$ : 0.23-0.26; adsorption capacity, \%: 60-62; ash weight fraction, \%: 10-12 [16].

Therefore, on the basis of the obtained data, it is possible to conclude that the application of porous coal, grade KAD-G, with the aim of 
Citation: Dzhakasheva MA, Kedelbayev BSh, Elemanova ZhR, Mamytova AY, Bissenov UK (2016) Extraction and Purification of Pectolytic Enzyme Using Combined Method. Biol Med (Aligarh) 8(2): BM-174-16, 4 pages.

discoloration of enzyme solutions and purification of culture liquids from pectic substances is efficient at the first stage. At $10 \mathrm{~g} / \mathrm{l}$ of sorbent, the purification degree in terms of color index is $63 \%$, and the specific activity of pectinase increases to $97.5 \%$ at the activity loss of $4.8 \%$.

In order to remove ionogenic impurities from enzyme solutions and to displace proteins, the filtrate of culture liquid was processed by strong-base ion-exchange resins: Amberlite CG-400 (US) and A500P (Great Britain), which can be used together with conventional coal adsorbents. Table 2 illustrates the influence of $\mathrm{pH}$ upon processing of the enzyme solution by strong anion-exchange resins.

The obtained data evidence that with increase in $\mathrm{pH}$ the purification degree in terms of color index increases and total pectolytic activity decreases. However, at high purification degree using ion-exchange resins, there occur high losses of enzyme solution. The best purification degree of enzyme solutions is observed upon application of A500P anion-exchange resin at $\mathrm{pH} 4$. This substance was specially developed for removal of anions of organic acids and for removal of nonionized mediums and high molecular organic compounds [17]. Macroporous structure of this anion-exchange resin provides high mechanical strength and good osmotic stability of the granules.

Complex extraction of pectolytic enzymes from partially purified solution was carried out by Si-hydroxyapatite in various concentrations for $30 \mathrm{~min}$ at $4^{\circ} \mathrm{C}$ and various $\mathrm{pH}$ of the solution (Figure 1).

As can be seen in Figure 1, the most optimum $\mathrm{pH}$ value of the solution, providing the highest purification degree (98\%), is 6 , at the concentration of nanosized Si-hydroxyapatite of $30 \mathrm{~g} / \mathrm{l}$. This is attributed to the fact that at $\mathrm{pH} 6$, pectinases are charged negatively and calcium ions positively, and due to interaction between charged functional groups, the enzyme solution is sorbed. Table 3 summarizes the results of processing of enzyme solution by nanosized Si-hydroxyapatite after desorption at various $\mathrm{pH}$; it can be seen that

\begin{tabular}{|c|c|c|c|c|}
\hline \multirow{2}{*}{$\begin{array}{c}\text { pH of } \\
\text { enzyme } \\
\text { solution } \\
\text { medium }\end{array}$} & \multicolumn{2}{|c|}{$\begin{array}{c}\text { Amberlite CG-400 } \\
\text { anion-exchange resin }\end{array}$} & \multicolumn{2}{c|}{ A500P anion-exchange resin } \\
\cline { 2 - 5 } & $\begin{array}{c}\text { Purification } \\
\text { degree in terms of } \\
\text { color index, } \%\end{array}$ & $\begin{array}{c}\text { PTA } \\
\text { activity } \\
\text { loss, } \%\end{array}$ & $\begin{array}{c}\text { Purification } \\
\text { degree in terms of } \\
\text { color index, } \%\end{array}$ & $\begin{array}{c}\text { PTA } \\
\text { activity } \\
\text { loss, } \%\end{array}$ \\
\hline 4 & 67 & 14.4 & 74 & 9.0 \\
\hline 5 & 70 & 21.0 & 76 & 10.0 \\
\hline 6 & 77 & 38.5 & 80 & 11.4 \\
\hline 7 & 82 & 67.0 & 91 & 58.0 \\
\hline
\end{tabular}

Table 2: $\mathrm{pH}$ influence during processing of the enzyme solution by strong anion-exchange resins

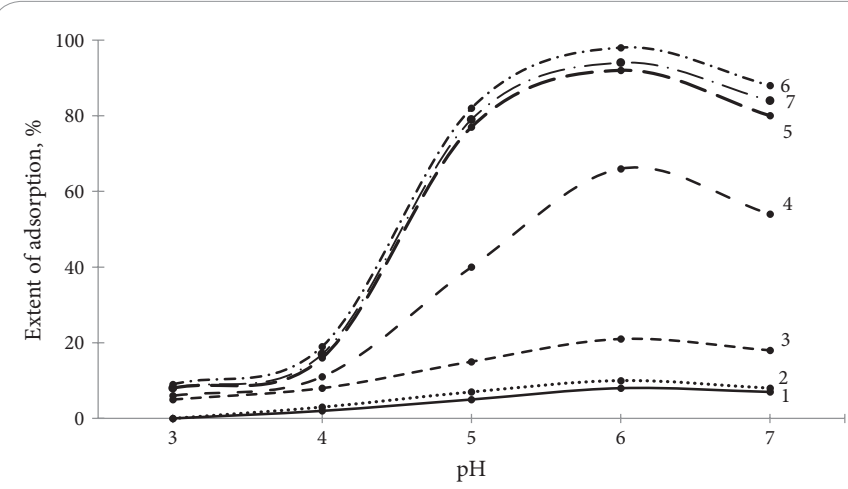

Curve identification, concentration of nanosized Si-hydroxyapatite, g/l: 1-5; 2-10; 3-15; 4-20; 5-25; 6-30; 7-35

Figure 1: Purification extent of enzyme solution as a function of $\mathrm{pH}$ and concentration of nanosized Si-hydroxyapatite

\begin{tabular}{|c|c|c|c|c|}
\hline $\begin{array}{c}\text { pH of } \\
\text { enzyme } \\
\text { solution } \\
\text { medium }\end{array}$ & PTA, \% & PGA, \% & $\begin{array}{c}\text { Purification } \\
\text { degree in terms } \\
\text { of color index, } \%\end{array}$ & $\begin{array}{c}\text { Specific activity, } \\
\text { units/mg protein }\end{array}$ \\
\hline 3 & 76 & 45 & 72 & 135.7 \\
\hline 4 & 82 & 51 & 74 & 170.0 \\
\hline 5 & 89 & 56 & 83 & 322.0 \\
\hline 6 & 95 & 69 & 92 & 425.5 \\
\hline 7 & 80 & 49 & 97 & 368.4 \\
\hline
\end{tabular}

Table 3: $\mathrm{pH}$ influence on performances of purification upon processing of enzyme solution after desorption of nanosized Si-hydroxyapatite

at $\mathrm{pH} 6$ maximum yield of activity of pectinase is achieved, equal to $95.0 \%$, polygalacturonase $-69.0 \%$, purification degree in terms of color index is $92.0 \%$, and specific activity -425.5 units/mg protein.

The obtained data evidence high efficiency of nanosized Si-hydroxyapatite for purification of pectolytic enzymes obtained upon application of A. awamori 56-2-53-85-375.

Desalinization of the stabilized enzyme solution and its concentrating were aided by diafiltration and ultrafiltration. The obtained concentrated product was lyophilically dried.

As a consequence of implementation of this method for group extraction of pectinase, the complex was obtained; variations of its characteristics stage by stage are summarized in Table 4 .

\begin{tabular}{|c|c|c|c|c|c|c|}
\hline \multirow[b]{2}{*}{ Indices } & \multicolumn{6}{|c|}{ Treatment stages } \\
\hline & Culture liquid & $\begin{array}{c}\text { Activated charcoal } \\
\text { KAD-G }\end{array}$ & $\begin{array}{l}\text { A500P anion- } \\
\text { exchange resin }\end{array}$ & Hydroxyapatite & Diafiltration & Ultrafiltration \\
\hline Volume, $\mathrm{ml}$ & 1,000 & 999 & 999 & 403 & 402 & 98 \\
\hline PTA, units/ml & 2.1 & 2.0 & 1.86 & 3.7 & 3.2 & 10.8 \\
\hline PGA, units/ml & 1.25 & 1.2 & 1.12 & 2.3 & 2.1 & 6.8 \\
\hline Protein, $\mathrm{mg} / \mathrm{ml}$ & 1.11 & 0.98 & 0.59 & 0.39 & 0.29 & 1.08 \\
\hline Specific activity, units/mg protein & 87.3 & 96.3 & 148.9 & 436.3 & 459.8 & 525.0 \\
\hline Activity loss, $\%$ & - & 1.5 & 9.5 & 26.3 & 35.2 & 39.2 \\
\hline $\begin{array}{l}\text { Purification degree in terms } \\
\text { of color index, } \%\end{array}$ & - & 63 & 80 & 92 & 95 & 99 \\
\hline
\end{tabular}

Table 4: Results of application of combined preparative method of enzyme production 
Citation: Dzhakasheva MA, Kedelbayev BSh, Elemanova ZhR, Mamytova AY, Bissenov UK (2016) Extraction and Purification of Pectolytic Enzyme Using Combined Method. Biol Med (Aligarh) 8(2): BM-174-16, 4 pages.

Page 4 of 4

Therefore, using sorption and ion exchange, we extracted and produced enzyme with high purification degree in terms of color index, 99\%; with specific activity of 525.0 units/mg protein; and with high yield of enzymes in terms of pectinase activity, 10.8 units $/ \mathrm{ml}$, and polygalacturonase activity, 6.8 units $/ \mathrm{ml}$. The developed method of purification takes into account the negative impact of ionic strength of solution on the efficiency of sorption and ion processes due to maximum $\mathrm{pH}$ of stability of pectolytic enzymes, since the most timeconsuming processing stages are performed at $\mathrm{pH}$ not higher than 4 .

\section{Conclusion}

Using adsorptive purification by KAD-G microporous charcoal and ion exchanging purification by A-500R anion exchange resin from culture liquid of A. awamori 56-2-53-85-375 enzyme solutions of pectinase were extracted with minimum decrease in total activity. The activation effect of enzyme solutions has been achieved by the use of nanosized Si-hydroxyapatite which, while interacting with enzyme molecules, displaces the remainders of substrate from allosteric and effector centers. Application of ultrafiltration and diafiltration demonstrated high efficiency of removal of low molecular impurities and desalinization of solutions from sufficiently high buffer concentrations obtained as a result of adsorptive and ion exchange purification. Implementation of the developed method of preparative production of pectolytic enzyme enables significant increase not only in the degree of pectinase purification-purification degree in terms of color index up to $99 \%$, but also the total yield of enzyme activity-more than by 6 times in terms of specific activity.

\section{References}

1. Gracheva IM, Krivova AY (2000) Technology of Enzymes. Moscow: Elevar.

2. Dontsov AG, Shubakov AA (2010) Pectolytic Enzymes: Purification, Activation, Microbiological Synthesis. Yekaterinburg: Ural Branch of Russian Academy of Science.

3. Uhlig H (1998) Industrial Enzymes and Their Applications. New York: A WileyInterscience Publication, John Wiley \& Sons, Inc.
4. Benen JAE, Vincken JP, Van Alebeek GJWM (2002) Microbial Pectinases in Pectins and Their Manipulation. Seymour GB, Knox JP (Eds). Boca Raton, FL: CRS Press.

5. Donchenko LV (2000) Technology of Pectin and Products Thereof. Moscow: DeLi Print.

6. Kosyura VT (2004) Fundamentals of Winemaking. Moscow: DeLi Print.

7. Sunnotel O, Nigam P (2002) Pectinolytic activity of bacteria isolated from soil and two fungal strains during submerged fermentation. World J Microbiol Biotechnol 18: 835-839.

8. Astapovich NI, Ryabaea NE (1997) Saccharomyces pastorianus polygalacturonase: extraction and certain properties. Prikl Biokhim Mikrobiol 33(3)

9. Kester HCM, Visser J (1990) Purification and characterization of polygalacturonases produced by the hyphal fungus Aspergillus niger. Biotechnol Appl Biochem 12: 150-160.

10. Dontsov AG, Popeiko OV, Arteyeva AV (2002) Production of pectolytic enzyme for structural and chemical analysis of polysaccharides. Proceedings of AllRussian Seminat, Barnaul.

11. Devi NA, Appu Rao AG (1996) Fractionation, purification and preliminary characterization of polygalacturonases produced by Aspergillus carbonarius. Enz Microb Technol 18(1): 59-65.

12. Lowry OH, Roserbrough NJ, Fan AL, Randall RJ (1951) Protein measurement with the Folin phenol reagent. J Biol Chem 193: 265-275

13. Le Van Thuan, Doan Van Dat, Temirkhanova GE (2011) Synthesis and study of morphology of silicon substituted nano-sized hydroxyapatite. Science Initiative of Foreign Students and Postgraduates of Russian Higher Schools: Proceedings of IV All-Russian Research and Practical Conference, Tomsk May 24-26, 2011. Tomsk: TPU Publishing House.

14. Dzhakasheva MA, Kedelbayev BS (2014) Getting the active strain of Aspergillus awamori-pectinase producer. Int J Appl Fundam Res 4. Date Views 11.04.2014, www.rae.ru.pdf.

15. Aikat K, Maiti T, Bhattacharyya B (2001) Decolorization and purification of crude protease Rhizopus oryzae by activated charcoal and its electroforetic analysis. Bitechnol Lett 23(4): 295-301.

16. Glushankov SL, Konopleva VV, Lyubchenko NG (1983) Active Coals. Index Cherkassy: NIITEKhIM.

17. Pathnak N, Sanwal GG (1998) Multiple forms of polygalacturonase from banana fruits. Phytochemistri 48(2): 249-255.
Citation: Dzhakasheva MA, Kedelbayev BSh, Elemanova ZhR, Mamytova AY, Bissenov UK (2016) Extraction and Purification of Pectolytic Enzyme Using Combined Method. Biol Med (Aligarh) 8(2): BM-174-16, 4 pages.

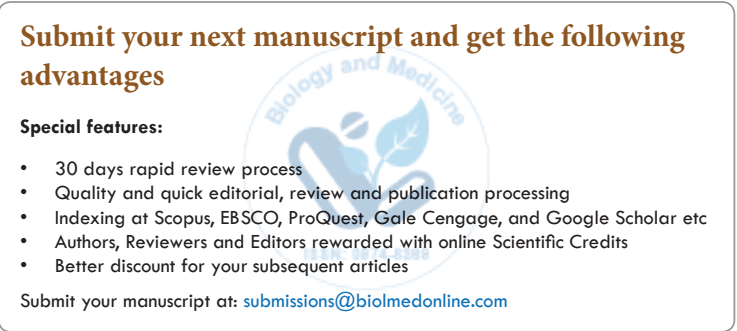

Submit your next manuscript and get the following dvantages

special features:

Quality and quick editorial, review and publication processing

Ter

Submit your manuscript at: submissions@biolmedonline.com 